\title{
RUSSIA'S AGRI-FOOD SECTOR: WEAK EXPORTS, LOW DEMAND ${ }^{1}$ N.Shagaida
}

Russia's agriculture industry continues to stay on the rise, but its growth rate is slowing down. Household disposable income are declining, thus weakening households' purchasing power. The growth in production and the decline in purchasing power are restraining food prices amid limited exports. Russian food producers are seeking ways to enter external markets.

Russia's agriculture industry continues to stay on the rise, but its growth rate slowed down in Q1 2016 compared to the same period of 2015 (Fig. 12).

Not all the agriculture sub-sectors have been affected by the slowdown in production growth rates. For example, in January-February 2016 Russia's pig farmers produced $10 \%$ more than at the same period previous year. Also, farmers produced more chicken eggs and meat than they did in the previous year, $3.9 \%$ and $6.3 \%$ respectively. Milk production growth rates ranged

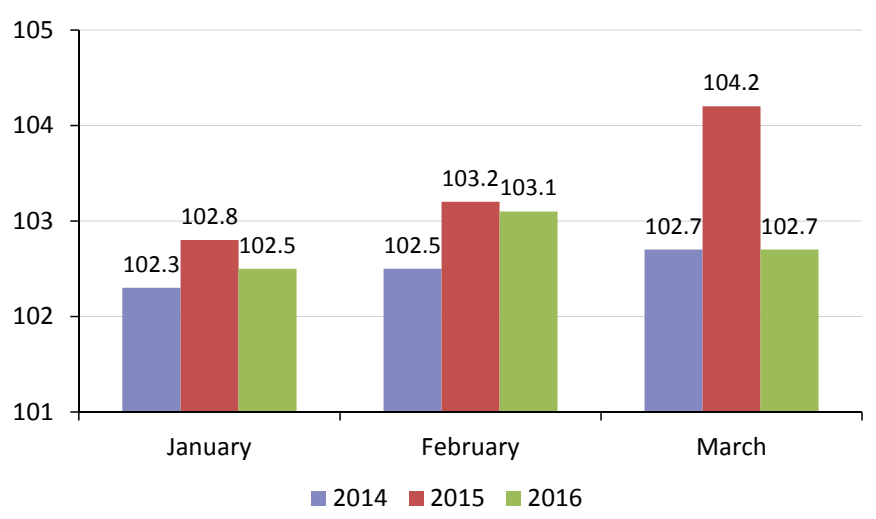

Source: Rosstat (Russia's Federal State Statistics Service).

Fig. 1. Agriculture production dynamics, \% change, period on the same period previous year within the limit of error (Table 1).

The Russian government have produced a great economic effect by shoring up farmers, but the state support has limits. Private subsidiary farms are not in the priority list for state support, although their share is big enough, e.g., they account for $46 \%$ of gross milk production in the country. The decline in production of these farms has not been offset by steady growth in other types of farms, as well as agriculture organizations.

Table 1

PRODUCTION DYNAMICS IN JANUARY-FEBRUARY VERSUS PREVIOUS YEAR, 2013-2016, TONS IN THOUSANDS (DATA AVAILABLE AS OF 10 MAY 2016)

\begin{tabular}{|l|c|c|c|}
\hline \multicolumn{1}{|c|}{ Production, tones in thousands } & 2014 & 2015 & 2016 \\
\hline Livestock and poultry for slaugh- & 3.5 & 7.7 & 5.9 \\
\hline ter on a live-weight basis & -3.3 & 2.5 & -0.8 \\
\hline Beef cattle & 3.3 & 8.2 & 0.8 \\
\hline Sheep and milk goats & 4.3 & 1.2 & -5.9 \\
\hline Other types of livestock & 3.8 & 12.5 & 6.3 \\
\hline Poultry & 7.9 & 4.0 & 10.2 \\
\hline Pigs & -1.1 & 1.5 & 1.3 \\
\hline Milk & -2.5 & 2.9 & 3.9 \\
\hline Eggs, pieces in millions
\end{tabular}

Source: Rosstat.

1 This paper was originally published in Online Monitoring of Russia's Economic Outlook No.8(26).

2 This information was prepared by Shishkina E.A. 
Russia's food industry is facing positive production dynamics, too, but it was only March that growth rates were higher (by fractions of a percent) than in the previous year (Fig. 2).

It appears to be logical that food production growth rates are slowing down due to a lack of streamlined export channels, because demand for food products has been on the slide since August 2014, as is evident from the retail sales index declining on a monthly basis (Fig. 3).

It was noted in previous releases of the Online Monitoring of Russia's Economic Outlook (OMREO No. 6 (24)) that people in Russia began to spend more on food products. Indeed, the share of food expenses neared $50 \%$ of the retail sales turnover in January 2016. However, it lost 3 p.p. in March (Fig. 4). Food and non-food inflation rates varied, as is seen from the diverging lines that show the trend in the share of food purchases in current prices and in the prices adjusted to 1 January 2013.

The reason for this dynamics of food sales is a change in household income and in food prices. Household income continued to decline (Table 2).

Fig. 5 shows that prices of various food products varied after a ban on food imports was imposed. For instance, prices of products of millions of stand-alone producers, whose imports and exports is inconsiderable, rose for a short term and then began to decline (e.g., potatoes). Taking advantage of the ban in the Russian market, Russian producers raised prices of their products (eggs, pork, poultry meat). Notably, pork prices began to pick up even before the food ban was announced, when Russia's Federal Service for Veterinary and Phytosanitary Surveillanc (Rosselkhoznadzor) introduced non-tariff restrictions to shut out pork imports of the Russian market. Prices continued to rise after the ban was introduced. Poultry meat prices picked up because this type of food products became a substitute to cover the shortfall in meat products. However, prices "got stuck on" effective demand and began to slide as early as the start of 2014. 
Table 2

DYNAMICS OF HOUSEHOLDS' REAL DISPOSABLE CASH INCOME, \% CHANGE, PERIOD ON THE SAME PERIOD PREVIOUS YEAR

\begin{tabular}{|l|l|l|}
\hline & 2015 & 2016 \\
\hline January & 98.0 & 94.5 \\
\hline February & 97.4 & 95.5 \\
\hline March & 97.6 & 98.2 \\
\hline Q1 & 97.7 & 96.1 \\
\hline
\end{tabular}

Source: Rosstat.

Cheeses and milk saw their price begin to rise shortly after the food ban was introduced, due to the fact that major EU cheese and dairy exporters left the Russian market while there was domestic underproduction of these products. Prices of flour, bread, vegetable oil (grains and vegetable oil are export-led products), sugar (an import-led product) began to rise following the Russian rouble devaluation. 2016 saw the price of the following staple foods fall: potatoes, pork, poultry meat and chicken eggs.

There is large difference between the growth of food prices in Russia (where the ban on food imports was introduced) and in the sanctioned countries (Table 3). The Table also shows various food inflation estimates made by Rosstat and OECD ${ }^{1}$. The OECD estimates are in most cases higher than the Rosstat official data.

Table 3

FOOD CONSUMER PRICE INDEX, \% CHANGE, PERIOD ON THE SAME PERIOD PREVIOUS YEAR

\begin{tabular}{|c|c|c|c|c|c|c|c|}
\hline & \multirow{2}{*}{$\begin{array}{c}\text { EU28 } \\
\text { (OECD } \\
\text { data) }\end{array}$} & \multicolumn{2}{|c|}{ Russia } & & \multirow{2}{*}{$\begin{array}{c}\text { EU28 } \\
\text { (OECD } \\
\text { data) }\end{array}$} & \multicolumn{2}{|c|}{ Russia } \\
\hline & & $\begin{array}{l}\text { OECD } \\
\text { data }\end{array}$ & $\begin{array}{c}\text { Rosstat } \\
\text { data }\end{array}$ & & & $\begin{array}{l}\text { OECD } \\
\text { data }\end{array}$ & $\begin{array}{c}\text { Rosstat } \\
\text { data }\end{array}$ \\
\hline \multicolumn{8}{|c|}{2015 from 2014} \\
\hline January & -1 & 22.8 & 20.7 & September & 0.4 & 19.1 & 17.4 \\
\hline February & -0.5 & 26.1 & 23.3 & October & 0.6 & 18.9 & 17.3 \\
\hline March & -0.3 & 25.9 & 23.0 & November & 0.5 & 17.7 & 16.3 \\
\hline April & 0.1 & 24.4 & 21.9 & December & 0.2 & 14.8 & 14.0 \\
\hline May & 0.5 & 22.4 & 20.2 & \multicolumn{4}{|c|}{2016 from 2015} \\
\hline June & 0.1 & 20.7 & 18.8 & January & 0.1 & 9.2 & 9.2 \\
\hline July & -0.3 & 20.4 & 18.6 & February & -0.1 & 6.0 & 6.4 \\
\hline August & 0.2 & 20.0 & 18.1 & March & 0 & 4.6 & 5.2 \\
\hline
\end{tabular}

Sources: Rosstat, OECD.

The volumes and the structure of import/export operations with food products have been changed due to a growth in the production of certain food products, a decline in food buying activity. In January-February 2016, food imports lost $8 \%$ from the same period previous year due to smaller supplies in January. Import volumes levelled off by February and reached the level seen in February 2015. This took place amid a much heavier shrinkage (18\%) of imports in Russia. As a result, the food share of imports increased up to $16 \%$ (Table 4).

Interestingly, imports have not been cut due to the growth in domestic meat production and the decline in effective demand: imports (on a weight basis) in January-February were $12 \%$ above the 2015 values, whereas there was a $4 \%$ decline in dollar terms. Values for dairy products were $+7 \%$ and $-10 \%$ respectively.

1 Organisation for Economic Co-operation and Development. 

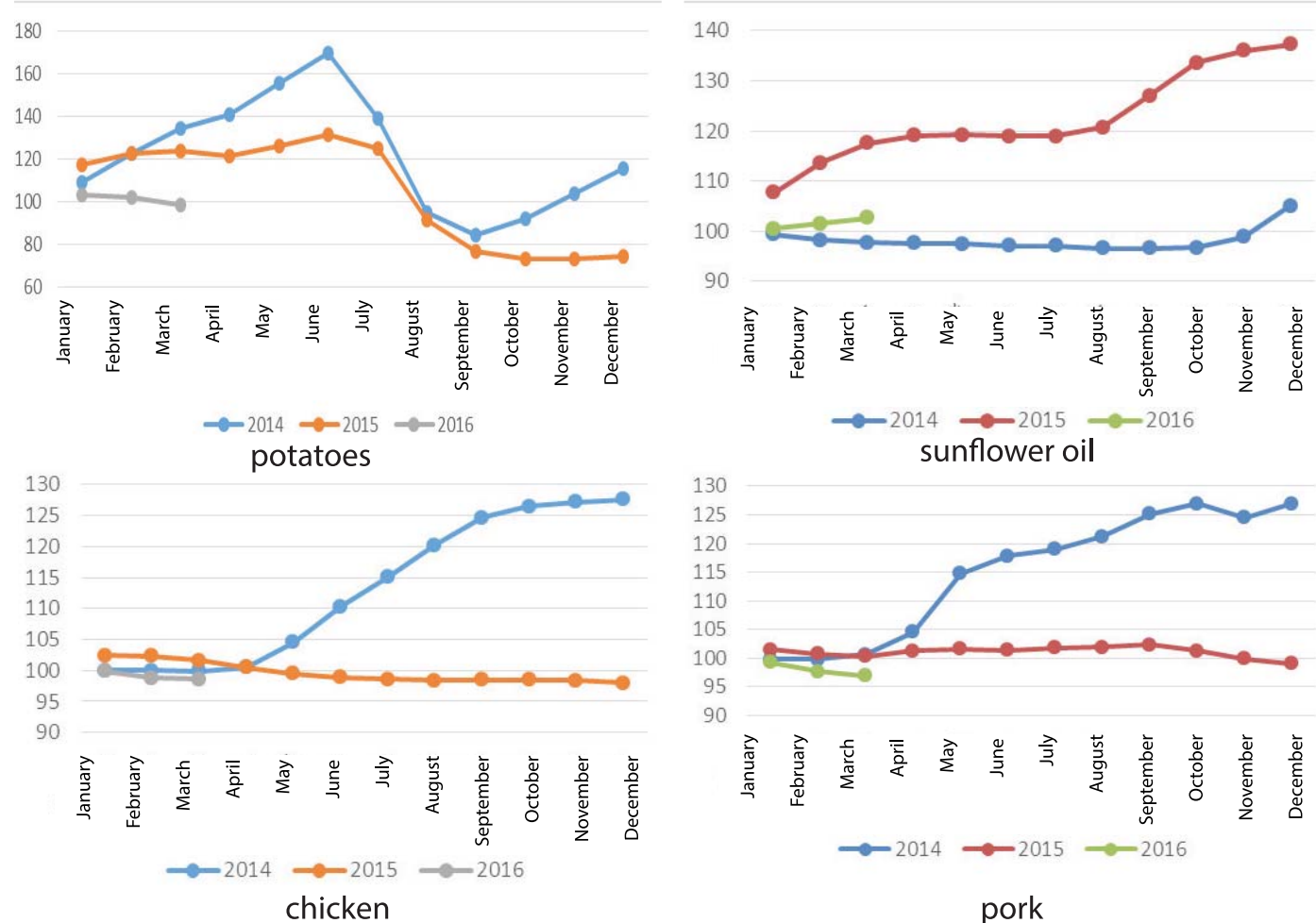

$\rightarrow 2014 \rightarrow 2015 \multimap-2016$ sunflower oil
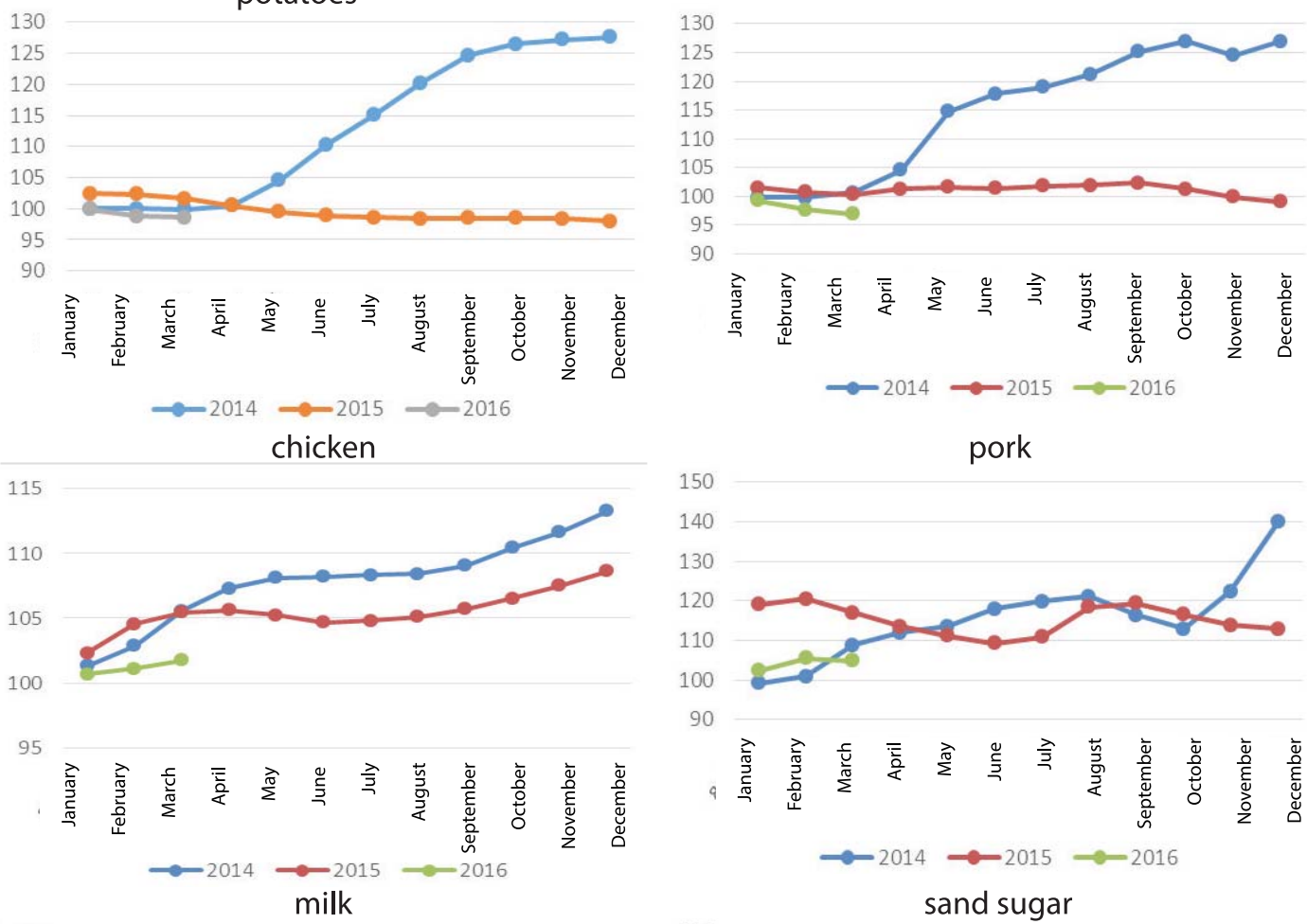

sand sugar
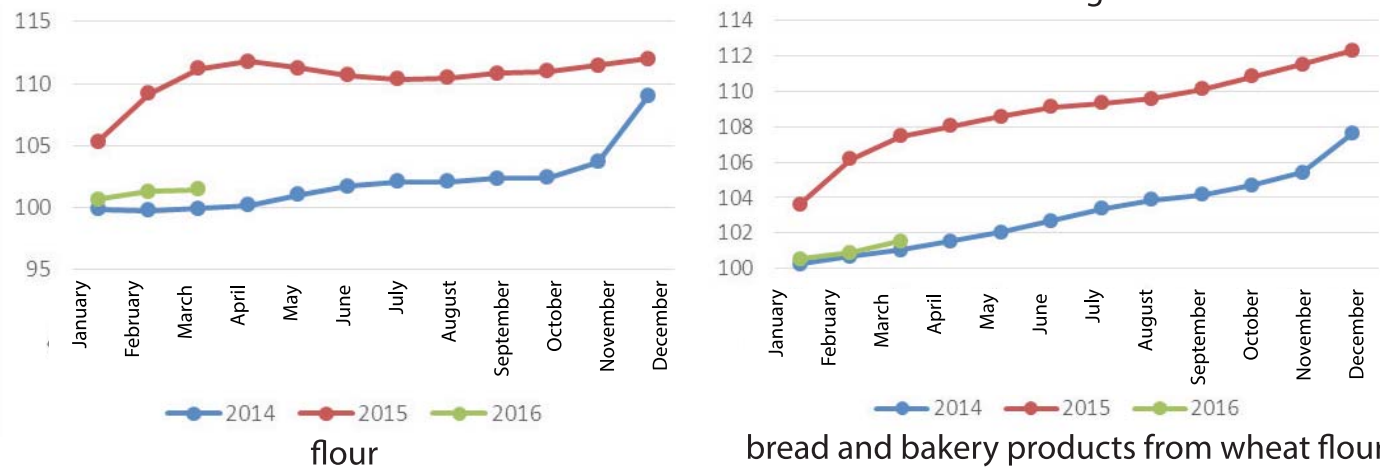

bread and bakery products from wheat flour

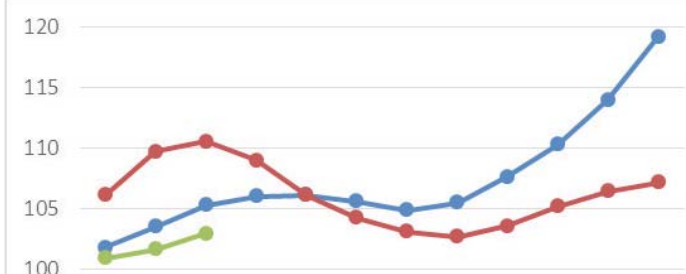

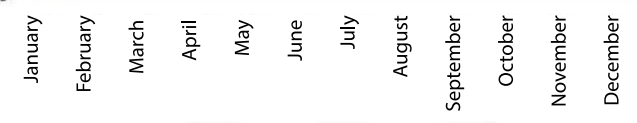
$\rightarrow 2014 \rightarrow 2015 \rightarrow-2016$

Source: Rosstat.

rennet

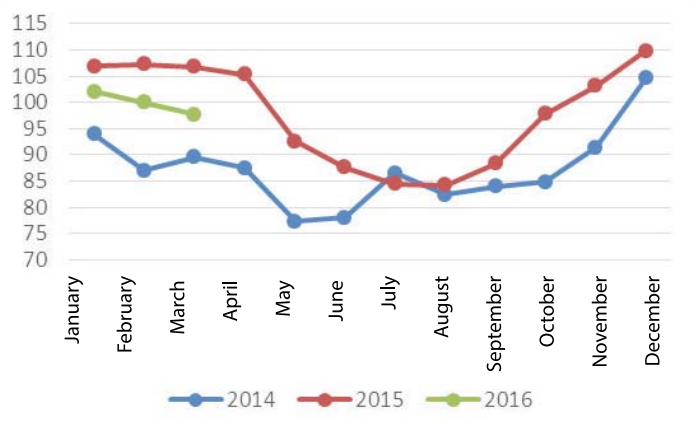

chicken eggs

Fig. 5. Consumer price indices, \% change, December on December previous year 


\begin{tabular}{|l|c|c|c|c|c|}
\hline & 2013 & 2014 & 2015 & $\begin{array}{c}\text { Jan-Feb } \\
2015\end{array}$ & $\begin{array}{c}\text { Jan-Feb } \\
2016\end{array}$ \\
\hline $\begin{array}{l}\text { Total } \\
\text { incl. } \\
\text { food and agriculture } \\
\text { products (1-24, according } \\
\text { to FEACN codes) }\end{array}$ & 315.30 & 287.06 & 182.72 & 25.82 & 21.14 \\
\hline $\begin{array}{l}\text { Share of goods 1-24 } \\
\text { according to FEACN, \% }\end{array}$ & 14 & 14 & 15 & 14 & 3.46 \\
\hline
\end{tabular}

Source: Russia's Federal Customs Service.

The structure of imports keeps changing. The share of meat products has shrunk drastically. If this could be explained by the fact that Russia's meat industry is on the brisk growth, then the shrunk share and decreased importance of dairy products should be given a special focus: the government should take decisions to make dairy products more affordable for people in Russia. Fruits and nuts continue to have the biggest share of the import structure. It is evident that this group of products will continue to prevail due to climatic characteristics of Russia.

The import structure is generally not an evidence of Russia's heavy reliance on any groups of food products. It is safe to say that this is normal structure of imports determined by the climate characteristics that make up a considerable share of the structure of imports of fruits, nuts, coffee, tea and tobacco (Table 5).

Table 5

\section{FOOD IMPORT STRUCTURE FOR MAJOR GROUPS (GROUPS WITH A SHARE OF IMPORTS GREATER THAN OR EQUAL TO 5\% ARE SELECTED ACCORDING TO FEACN CODES), \%}

\begin{tabular}{|l|c|c|c|c|}
\hline \multicolumn{1}{|c|}{$\begin{array}{c}\text { Groups of food products } \\
\text { according to FEACN codes }\end{array}$} & 2013 & 2015 & $\begin{array}{c}\text { Q1-Q2 } \\
2015\end{array}$ & $\begin{array}{c}\text { Q1-Q2 } \\
2016\end{array}$ \\
\hline $\begin{array}{l}\text { 1-24 - food products } \\
\text { 02 - meat and edible meat offal }\end{array}$ & 100 & 100 & 100 & 100 \\
\hline $\begin{array}{l}\text { 03 - fish and crustasea, molluscs } \\
\text { and other aquatic invertebrates }\end{array}$ & 6.6 & 5.1 & 4.7 & 5.3 \\
\hline $\begin{array}{l}\text { 04 - dairy products; hen's eggs; natural } \\
\text { honey; food products of animal origin }\end{array}$ & 10.3 & 7.7 & 7.8 & 7.6 \\
\hline $\begin{array}{l}\text { 07 - vegetables and some } \\
\text { edible roots and tubers }\end{array}$ & 6.7 & 7.2 & 8.6 & 6.8 \\
\hline $\begin{array}{l}\text { 08 - edible fruits and nuts; citrus } \\
\text { fruit peels or melon peels }\end{array}$ & 14.8 & 14.9 & 16.3 & 17.9 \\
\hline $\begin{array}{l}\text { 09 - coffee, tea, mate or } \\
\text { Paraguay tea, and spices }\end{array}$ & 2.9 & 4.6 & 5.1 & 4.7 \\
\hline $\begin{array}{l}\text { 12 - oil seeds and fruits; other seeds, } \\
\text { fruits and kernels; medicinal }\end{array}$ & 3.1 & 5.7 & 6.7 & 6.4 \\
\hline $\begin{array}{l}\text { 22 - alcoholic and non-alcoholic } \\
\text { beverages and vinegar }\end{array}$ & 7.9 & 6.7 & 5.1 & 4.7 \\
\hline $\begin{array}{l}\text { 24 - tobaccos and industrial } \\
\text { tobacco substitutes }\end{array}$ & 3.1 & 4.2 & 4.4 & 5.7 \\
\hline
\end{tabular}

Source: Russia's Federal Customs Service.

In dollar terms, exports in M2 2016 remained almost unchanged compared to 2015 (a growth of 1.1\%). However, exporters' earnings swelled by 
$23 \%$ because of the rouble devaluation. In this regard, export operations remained extremely attractive to Russian exporters due to the growth in rouble earnings while exports in dollar terms remained intact (Table 6).

Table 6

EXPORTS OF FOODS AND AGRICULTURE PRODUCTS IN JANUARY-FEBRUARY IN A PARTICULAR YEAR

\begin{tabular}{|l|c|c|c|c|c|c|c|c|c|}
\hline & 2013 & 2014 & 2015 & 2016 & 2013 & 2014 & 2015 & 2016 \\
\hline & US dollars in millions \\
\hline January & 889 & 1024 & 1184 & 915 & 27 & 34 & 73 & 70 \\
\hline February & 969 & 1309 & 1100 & 1393 & 29 & 46 & 71 & 107 \\
\hline Total & 1858 & 2332 & 2284 & 2308 & 56 & 80 & 144 & 177 \\
\hline
\end{tabular}

Source: Russia's Federal Customs Service.

In 2016, food export earnings remained unchanged as total exports from Russia were cut by $34 \%$. Table 7 shows a change in the food export structure with prevailing groups of export products.

Table 7

\section{FOOD EXPORT STRUCTURE FOR MAJOR GROUPS (GROUPS WITH A SHARE OF IMPORTS GREATER THAN OR EQUAL TO 5\% ARE SELECTED ACCORDING TO FEACN CODES), \%}

\begin{tabular}{|c|c|c|c|c|c|}
\hline & 2013 & 2015 & $\begin{array}{c}\text { Q1-Q2 } \\
2015\end{array}$ & $\begin{array}{l}\text { Q1-Q2 } \\
2016\end{array}$ & $\begin{array}{c}2016 / 2015 \\
\text { by value }\end{array}$ \\
\hline 1-24-food products & 100 & 100 & 100 & 100 & 101.07 \\
\hline $\begin{array}{l}03 \text { - fish and crustasea, molluscs } \\
\text { and other aquatic invertebrates }\end{array}$ & 17.3 & 17.2 & 14.2 & 15.7 & 111.8 \\
\hline $10-$ cereals & 29.2 & 34.9 & 34.2 & 35.8 & 105.8 \\
\hline $\begin{array}{l}15 \text { - fats and oils of animal } \\
\text { or vegetable origin and } \\
\text { spit products thereof }\end{array}$ & 13.4 & 11.6 & 16.0 & 15.3 & 96.7 \\
\hline $\begin{array}{l}23 \text { - food-industry residues } \\
\text { and wastes; ready-made } \\
\text { feed for animals }\end{array}$ & 6.4 & 6.0 & 9.5 & 6.3 & 67.6 \\
\hline
\end{tabular}

In January-February 2016, exports (on a value basis) of grains and fish increased compared to the same period previous year. Considering that people in Russia are facing shortage of fish products on their dinner tables, the growth in fish exports is not an evidence of positive trends. A double increase in meat exports ( $1 \%$ of the value structure of exports) and a $27 \%$ growth of dairy products ( $1 \%$ of the export structure) can be distinguished among exports of products that have an inconsiderable share of the export structure but they are very important for people in Russia because of traditional shortage of these products. The increase in exports of vegetables appears to be promising because there is no doubt Russia has a huge potential for growing open-field seasonal vegetables ( $+79 \%$ according to the value of exports, with a $2.2 \%$ share of exports). In addition, exports of oleaginous fruits rose by $23 \%$ (with a $3.6 \%$ share of exports), flour-and-cereals products was up $16 \%$ (1\% of the structure), confectioneries by $11 \%$ ( $1 \%$ of the structure).

Russia's agriculture industry is being affected by low effective demand. Exports are weak. It is obvious that it would be useful at this point to develop the domestic agro-processing industry and to seek ways for Russian food brands to enter external markets in order to develop Russia's agri-food sector. 